\title{
PERSPEKTIF BARU METODE DAN ALIRAN TAFSIR IBN QAYYIM
}

(Telaah Metode dan Aliran Tafsir at-Tibyan fi Aqsamil Qur'an)

\author{
Abdul Muhaimin \\ Dosen Ilmu al-Qur'an dan Tafsir Institut Pesantren KH. Abdul Chalim \\ abdmuha356@gmail.com \\ Mas'ulil Munawaroh \\ Sekolah Tinggi Agama Islam Sabilul Muttaqin Mojokerto \\ munawaroh1980@gmail.com
}

\begin{abstract}
Qasam in the Koran shows the seriousness of Allah to convey material or strengthen arguments because of the lack of faith in the material delivered. This shows that knowing Qasam in the Qur'an is very urgent and it is not surprising if in the end Imam Ibn Qayyim al-Jauziyyah wrote a specific account explaining the Qasam in the Qur'an in his interpretation called "at-Tibyan fi Aqsamil Qur'an". Therefore it is necessary to do a study to find out new perspectives of sources, methods and interpretations according to M. Ridlwan Nasir, thus adding insight into our study in the study of commentaries. The problem in this study is what sources, methods and interpretive flows are used in the tafsir "at-Tibyan fi Aqsamil Qur'an". The results of the research that the research source used is bil Iqtiran (a combination of bil Ma'tsur and bil Ra'y), The method of the explanation uses the Bayan methodi , in terms of the breadth of the explanation using the Itnabi method, and seen from the goals \& objectives of the verse interpreted using the Maudu'i method. While the flow / tendency, the flow Sufi, Lughawi, 'Ilmi, and alFiqhi, but the most dominant flow is the Sufi.
\end{abstract}

Keywords: New Perspective, Interpretation of Ibn Qayyim, Method, Flow

\begin{abstract}
Abstrak
Qasam dalam Al-Quran menunjukkan keseriusan Allah untuk menyampaikan materi atau menguatkan argumentasi karena keingkaran mukhathab (lawan bicara) pada materi yang disampaikan. Hal ini menunjukkan bahwa mengetahui Qasam dalam Al Quran sangat urgen sekali dan tidak heran jika pada akhirnya Imam Ibn Qayyim al-Jauziyyah menulis sebuah buku yang spesifik menjelaskan tentang Qasam dalam Al-Qur'an dalam tafsirnya yang dinamakan 'at-Tibyan fi Aqsamil Qur'an. Oleh sebab itu perlu dilakukan kajian untuk mengetahui perspektif baru sumber, metode dan aliran tafsir menurut M. Ridlan Nasir, sehingga menambah wawasan kajian kita dalam studi kitab tafsir. Permasalahan dalam penelitian ini adalah sumber, metode dan aliran penafsiran yang digunakan dalam tafsir "at-Tibyan fi Aqsamil Qur'an. Hasil penelitian bahwa Sumber penelitian yang digunakan adalah bil Iqtiran (perpaduan antara bil Ma'tsur dan bil Ra'y), Metode dari cara penjelasannya menggunakan metode Bayani, dari sisi keluasan penjelasannya menggunakan metode Itnabi, dan dilihat dari sasaran \& dan sasaran ayat yang ditafsirkan menggunakan metode Maudu'i. Sedangkan aliran/kecenderungannya, aliran Sufi, Lughawi, 'Ilmi, dan al-Fiqhi, namun aliran yang paling dominan adalah aliran Sufi.
\end{abstract}

Kata Kunci: Perspektif Baru,Tafsir Ibn Qayyim,Metode, Aliran

\section{A. PENDAHULUAN}

Al-Qur'an banyak sekali menyebutkan kalimat Qasam sebagai penguat argumentasi yang disampaikan Allah Swt. Secara teori Qasam disampaikan karena ada faktor yang melatarbelakanginya, diantaranya yaitu keingkaran mukhathab terhadap materi yang disampaikan. Hal ini menunjukkan bahwa kalimat yang disertai Qasam merupakan masalah yang yang sangat penting untuk dikaji dan dipahami 
secara detail. Oleh karenanya tidak heran jika Imam Ibn Qayyim al-Jauziyyah menulis sebuah tulisan yang spesifik menjelaskan tentang Qasam dalam Al-Qur'an dalam tafsirnya yang dinamakan “at-Tibyan fi Aqsamil Qur'an”.

Selanjutnya berkaitan dengan tafsir tersebut, tujuan penulis dalam tulisan ini adalah untuk mengetahui lebih lanjut tentang sumber, metode dan aliran atau aliran tafsir yang digunakan oleh Ibn Qayyim dan tafsir at-Tibyan tersebut Perspektif Baru Metode dan Aliran Tafsir yang ditawarkan oleh M. Ridlwan Nasir. Oleh sebab itu perlu adanya kajian secara mendalam dalam tafsir ini untuk mengetahui sumber, metode dan aliran tafsir yang digunakan sehingga menambah wawasan kajian kita dalam studi kitab tafsir.

Setidaknya ada empat aspek yang akan menjadi landasan dalam menganalisis metode (manhaj) sebuah tafsir yaitu tentang sumber penafsiran, cara penjelasan, keluasan penafsiran, dan aspek sasaran serta tertib ayat dan tujuh aspek untuk menganalisa aliran (naz'ah) sebuah tafsir yaitu lughawi/adabi, fiqih/ahkam, shufi, i'tiqadi, falsafi, 'ashri (ilmi) dan Ijtimai'. '

\section{RUMUSAN MASALAH}

Berdasarkan dari penjelasan di atas, maka yang menjadi permasalahan dalam penelitian ini adalah sebagai berikut:

1. Apa sumber penafsiran yang digunakan dalam tafsir at-Tibyan fi Aqsamil Qur'an?

2. Metode apa yang digunakan dalam at-Tibyan fi Aqsamil Qur'an?

3. Aliran atau aliran apa yang terdapat dalam at-Tibyan fi Aqsamil Qur'an?

\section{METODE PENELITIAN}

1. Sifat dan Sumber Penelitian

Penelitian ini, ditinjau dari segi sifat-sifat data termasuk dalam penelitian kualitatif (Qualitatif Research) dan beraliran library murni. Dikarenakan kajian ini merupakan analisis pada kitab tafsir, maka sumber pertama dan utama (primer) adalah kitab at-Tibyan fi Aqsamil Qur'an karya Ibn Qayyim.

${ }^{1}$ Ridwan Nasir, Memahami Al-Qur'an: Perspektif Baru Metodologi Tafsir Muqarin, (Surabaya: Indra Media, 20030, 13-19. 


\section{Metode Pendekatan dan Analisis}

Karena obyek studi ini adalah kitab tafsir, maka pendekatan yang dipilih di dalamnya adalah pendekatan ilmu tafsir. Sebagaimana penjelasan sebelumnya bahwa dalam menganalisis metode (manhaj) sebuah tafsir perlu mengetahui empat aspek yaitu tentang sumber penafsiran, cara penjelasan, keluasan penafsiran, dan aspek sasaran serta tertib ayat dan serta tujuh aspek untuk menganalisa aliran (naz'ah) sebuah tafsir yaitu lughawi/adabi, fiqih/ahkam, shufi, I'tiqadi, falsafi, 'ashi (ilmi) dan Ijtimai'.

Dikarenakan data yang digunakan berupa dokumen atau telaah pustaka, maka metode yang sesuai untuk menganalisisnya adalah metode analisis isi (content analysis). Salah satu teknis content analysis adalah menggunakan kriteria sebagai dasar klasifikasi dan menggunakan teknik analisis tertentu sebagai pembuat prediksi. Secara deskriptif teori ini menampilkan obyektifitas, pendekatan sistematis dan generalisasi, ${ }^{2}$ yang disesuaikan sedemikian rupa dengan pendekatan tafsir.

\section{B. PEMBAHASAN}

\section{Biografi Dan Karya Al-Imam Ibn Al-Qayyim Al-Jauziyyah}

Beliau adalah Imam, 'Allamah, Muhaqqiq, Hafiz, Ushuli, Faqih, Ahli Nahwu, berotak cemerlang, bertinta emas dan banyak karyanya; Shamsuddin Abu Abdillah Muhammad bin Abi Bakr bin Ayyub bin Sa'ad bin Huraiz al-Zar'i, kemudian adDimashqi. Dikenal dengan Ibn al-Qayyim al-Jauziyyah nisbat kepada sebuah madrasah yang dibentuk oleh Muhyiddin Abu al-Mahasin Yusuf bin Abd al-Rahman bin Ali al-Jauzi yang wafat pada tahun $656 \mathrm{H}$, sebab ayah Ibn al-Qayyim adalah tonggak (Qayyim) bagi madrasah itu. Ibn al- Qayyim dilahirkan di tengah keluarga berilmu dan terhormat pada tanggal 7 Saffar $691 \mathrm{H}$. Di kampung Zara' dari perkampungan Hauran, sebelah tenggara Dimashqi (Damaskus) sejauh 55 mil.

Ia memulai pendidikannya di madrasah al-Jauziyah di bawah pengawasan langsung dari ayahnya yang ketika itu adalah pengelola madrasah tersebut.

\footnotetext{
${ }^{2}$ Badar Thomthomi, "Penegakan Hukum dalam Konteks Keindonesiaan: Studi Analisis Hukum Positif dan Hukum Islam terhadap Penegakan Hukum Korupsi di Indonesia”, Tesis IAIN Sunan Ampel Surabaya, 2006.
} 
Al-Jauziah adalah nama sekolah di Damskus yang dibangun oleh seorang yang dikenal dengan nama Abd al-Rahman al-Jauzy. Madrasah ini merupakan salah satu madrasah Hambaliyah terbesar di kota Damshiq ketika itu. Selanjutnya ia pernah rihlah 'ilmiyah ke Mesir dan ke Mekkah. ${ }^{3}$

Kedudukannya sebagai putra seorang pendidik membuatnya sangat mencintai ilmu sejak masa mudanya, sehingga berbagai macam disiplin ilmu agama ia kuasai. Ibn Qayyim berguru kepada al-Shihab al-Nabulsi, Abu Bakar bin al-Dayim, al-Qadi Taqiyyuddin Salman, 'Isa al-Mut'im, Fatimah bint Jauhar, Abu Nashar Muhammad bin 'Imaduddin al-Shairazi, Ibn Maktum, al-Bhanaa bin 'Asakir, al-Qadi Badr al-din bin Jama'ah dan lain-lainya. ${ }^{4}$

Diantara semua guru Ibn Qayyim al-Jauziyah Shaikh ibn Taimiyah adalah yang paling terkesan dan banyak membentuk sikap ilmiyah dan pribadinya, dan merupakan profil yang diidolakan olehnya. Ia bergaul dengan gurunya tersebut mulai tahun 712 H. Sejak kembali ke damaskus, setelah tinggal selama tujuh tahun di Mesir hingga $718 \mathrm{H}$., ia belajar darinya ilmu tafsir, hadis, fiqh, faraid, Usul fiqh dan teologi. $^{5}$

Ibn Qayyim al-Jauziyah memperdalam pendapat Ibn Taimiyah setelah ia kembali ke Mesir pada tahun $712 \mathrm{H}$. Jika fokus perhatian Ibn Taimiyah pada masa hidupnya dalam masalah fiqh, fatwa dan aqidah, maka Ibn Qayyim al-Jauziyah mengambil fiqhnya dan menggunakan metodologinya. ${ }^{6}$

Ibn Qayyim al-Jauziyah pernah mengalami musibah seperti yang dialami Ibn Taimiyah. Mereka sama-sama di penjara di Benteng damaskus setelah ditarik dengan seekor onta yang dipukul dengan tongkat. Dia memanfaatkan masa-masa dipenjara dengan beribadah, membaca al-Qur'an dan berfikir. Tragisnya, dia tidak pernah dikeluarkan dari penjara, kecuali setelah Ibn taimiyah meninggal dunia.

Ibn al-Qayyim benar-benar telah menyediakan dirinya untuk mengajar, memberi fatwa, berdakwah dan melayani dialog. Karena itulah banyak manusiamanusia pilihan dari kalangan para pemerhati yang menempatkan ilmu sebagai

\footnotetext{
${ }^{3}$ Ibn Kathir, al-Bidayah wa al-Nihayah, (t.tp. Dar Ihya' al-Turath al-“arabi, 1988), Juz XIII, 221

${ }^{4}$ Kamil Muh\}ammad Muh\}ammad 'Uwaydah, al-Imam al-Hafiz Shams al-Din, (Beirut: Dar al-Kutub al-Ilmiyyah, t.th), Cetakan ke-1, 2.

${ }^{5}$ Ibn Kathir, al-Bidayah wa al-Nihayah..., 15.

${ }^{6 I b n}$ Qayyim, al-Fawaid, (Beirut, Dar al-Kutub al-'Ilmiyah, 1973), 16.
} 
puncak perhatiannya, telah benar-benar menjadi murid beliau. Mereka itu adalah para ulama terbaik yang telah terbukti keutamaannya, di antaranya ialah: anak beliau sendiri bernama Syarafuddin Abdullah, anaknya yang lain bernama Ibrahim, kemudian Ibnu Kathir ad-Dimasyqiy penyusun kitab al-Bidayah wan Nihayah, alImam al-Hafizh Abdurrahman bin Rajab al-Hambali al-Baghdadi penyusun kitab Thabaqat al-Hanabilah, Ibn Abd al-Hadi al-Maqdisi, Shamsuddin Muhammad bin Abd al-Qadir an-Nablisiy, Ibn Abd al-Rahman an-Nablisiy, Muhammad bin Ahmad bin Uthman bin Qaimaz al-Dhahabi at-Turkumaniy asy-Syafi'i, Ali bin Abd 1-Kafi bin Ali bin Taman al- Subky, Taqiyuddin Abu al-Thahir al-Fairuz al-Syafi'i dan lain-lain.

Adapun karya-karya Ibn Qayyim diantaranya adalah:

a. Tahdzib Sunan Abi Dawud

b. I'lam al-Muwaqqi'in 'an Rabbil 'Alamin

c. Ighatsatul Lahfan fi Hukmi Thalaq al-Ghadlban

d. Ighatsatul Lahfan fi Masha id al-Syaitan

e. Badai' al-Fawa'id

f. Amthal al-Qur'an

g. Butlan al-Kimiya' min Arba'ina wajhain

h. Bayan a-Dalil 'ala istighna' al-Musabaqah 'an a-Tahlil

i. at-Tibyan fi Aqsamil Qur'an

j. at-Tahrir fi ma yahillu wa yahrum min al-haris

k. Safr al-Hijratain wa Babus Sa'adatain

1. Madarij al-Salikin bain Manazil Iyyaka na 'budu wa Iyyaka Nasta'in

m.Aqd al-Muhkamil Ahya' bai al-Kalim al- Tayyib wa al-Amal al-Salih alMarfu' ila Rabbi al-Sama'

n. Syarh Asma' al-Kitab al-Aziz

o. Zad al-Ma'ad fi Hadyi Khairul Ibad

p. Zadul Musafirin ila Manazil al-Su'ada'fi Hadyi Khatam al-Anbiya'

q. Jala' al-Afham fi dzkr al-shalati 'ala Khair a-lAnam

r. Hadi al-Arwah ila bilad al-Arrah

s. Nuzhat al-Musytaqin wa raudlat al-Muhibbin

t. al-Jawab al-Kafi Li man sa 'ala 'an al Dawa i al-Shafi 


\author{
u. Tuhfat al-Wadud bi Ahkam al-Maulud \\ v. Fad\}l al-'Ilmi \\ w. al-Farqu bain al-Khullah wa al-Mahabbah wa Munazarat al-Khalil li \\ Qaumihi \\ x. al-Thuruq al-Hikamiyyah ${ }^{7}$
}

\title{
Sistematika Penulisan Tafsir Al-Tibyan
}

Sistematika penulisan kitab Tafsir al-Tibyan dapat disimpulkan sebagai berikut:

1. Pemetaan pembahasan menggunakan istilah "fasl" yang dimulai dari fasl 1 sampai fasl 151.

2. Fasl pertama menjelaskan tentang istilah-istilah yang berkaitan dengan qasam (qasam, muqsam bih dan muqsam 'alaih).

3. Fasl kedua menjelaskan secara global tentang ayat-ayat yang berkenaan dengan muqsam 'alaih sesuai dengan kelompoknya (pokok-pokok keimanan, rasul, pembalasan, janji dan ancaman, keadaan dan sifat manusia).

4. Fasl ketiga dan seterusnya membahas secara detail tentang muqsam 'alaih disertai dengan argumen ijitihad Ibn Qayyim dan terkadang diperkuat dengan hadis dan pendapat sahabat, tabi'in dan para ulama.

\section{Komentar Terhadap Tafsir Al-Tibyan}

1. Keistimewaan Tafsir al-Tibyan

Sebagaimana yang telah disebutkan di atas, Ibn Qayyim al-Jauziyah merupakan ulama yang kreatif dan sangat mencintai ilmu. Oleh karena itu, banyak sekali buku-buku karya beliau termasuk diantaranya adalah kitab yang sedang penulis kaji yaitu “al-Tibyan fi Aqsam al-Qur'an”.

Terkait dengan kitab ini, hingga makalah ini ditulis penulis belum menemukan buku yang menjelaskan tentang komentar para ulama. Hal ini dikarenakan keterbatasan refrensi penulis. Namun, jika dilihat dari sisi penulisnya yang mempunyai dedikasi tinggi dalam berbagai keilmuan

\footnotetext{
${ }^{7}$ Ibn Qayyim, al-Fawaid, (Beirut, Dar al-Kutub al-'Ilmiyah, 1973), 29-32
} 
sebagaimana telah dijelaskan dalam riwayat hidupnya, kitab ini tentunya mempunyai beberapa keistimewaan. Sebatas pengamatan penulis keistimewaan yang terdapat dalam kitab ini diantaranya adalah;

a. Kitab ini termasuk di antara salah satu kitab yang sangat komprehensif dalam membahas tentang hal-hal yang berkenaan dengan sumpah dalam alQur'an.

b. Dalam pembahasannya, Ibn Qayyim banyak mengkaitkan sumpah dengan muqsam 'alaih dan menganalisis dengan sangat detail.

c. Penyajian tafsir meliputi beberapa aspek, dimulai dari aspek bahasa, kejiwaan, pengetahuan umum, dan aspek fiqh.

\section{Kelemahan Tafsir Al-Tibyan}

Sebagai karya manusia yang tak luput dari kelemahan, dalam kitab ini tentunya terdapat pula kelemahan. Adapun kelemahan kitab ini sebatas pengamatan penulis diantaranya adalah;

a. Bab dan sub-babnya hanya ditulis dengan fasl tidak ditulis sesuai pembahasannya, sehingga sulit bagi pembaca untuk mencari bab yang diinginkan.

b. Sering terjadi pengulangan pembahasan dengan ayat yang sama tapi pembahasan berbeda.

c. Sering menggunakan bahasa yang kurang populer, sehingga bagi pembaca pemula sulit untuk memahami.

\section{Metode Tafsir Al-Tibyan fi Aqsam Al-Qur'an}

Ulama era abad ke-9 hingga ke-13 memetakan metode tafsir dalam tiga bentuk;tafsir bi al-ma'thur, tafsir bi al-ra'y, dan tafsir al-ishari. ${ }^{8}$ Kemudian muncul ulama-ulama kontemporer yang berusaha merumuskan kembali tafsir-tafsir yang ada. Husain al-Dhahabi membagi tafsir menjadi lima bagian, yakni tafsir ma'thur

${ }^{8}$ Pendapat ini diikuti oleh ulama-ulama kontemporer seperti 'Ali al-Sabuni, 'Abd al-'Azim alZarqani, Subhi al-Salih.Lihat 'Ali al-Sabuni, al-Tibyan fi 'Ulum al-Qur'an (Beirut: Dar al-'Ilm alKutub, t.th.), 67, 155, dan 171. Subhi Salih, Mabahith fi 'Ulum al-Qur'an (Beirut: Dar al-'Ilm alMalyin, 1988), 291-296. Abd al-'Azim al-Zarqani, Manahil al-'Irfan fi 'Ulum al-Qur'an, vol. II (Kairo: Dar al-Hadith, 2001), 14. 
(riwayat), tafsir ra'y atau 'Aql (nalar), tafsir mau'du'i (tematik), tafsir isyari (intuisi), dan tafsir 'ilmi (sains/ilmu pengetahuan). ${ }^{9}$

Sedangkan Abd al-Hayy Al-Farmawi membagi metode-metode yang dikenal selama ini menjadi empat kelompok; tahlili (analisis), ijmali (global), Muqarin (komparatif), dan Maudu 'i (tematik). ${ }^{10}$

Adapun definisi metode-metode tersebut di atas adalah sebagai berikut:

1. Metode tahlili adalah suatu cara kerja penafsiran ayat-ayat al-Qur'an sesuai dengan runtutan ayat dan surat yang terdapat dalam al-Qur'an, serta mejelaskan hal-hal yang berhubungan dengan setiap ayat, baik berupa makna, kosa kata, gramatika, sastra, hukum, sebab turunnya ayat dan yang lainnya. ${ }^{11}$ Metode ini menitik beratkan menitikberatkan pada uraian-uraian penafsiran yang detail, mendalam, dan komprehensif sehingga dapat memberikan berbagai informasi tentang teks, sejarah, linguistik, kondisi sosial dan hal-hal yang berkaitan dengan teks ayat yang ditafsirkan. ${ }^{12}$

2. Metode Ijmali adalah suatu penafsiran ayat-ayat al-Qur'an, dimana penjelasan yang dilakukan cukup singkat dan global. Dengan kata lain penafsiran dengan metode ini berusaha mejelaskan ayat-ayat al-Qur'an secara ringkas tetapi dengan menggunakan bahasa yang populer, mudah dimengerti dan enak dibaca. $^{13}$

3. Metode Muqarin adalah suatu metode penafsiran yang mengumpulkan berbagai keterangan-keterangan tentang penafsiran sebuah ayat yang masih dalam satu pembahasan (baik berupa ayat al-Quran, dengan hadis, pendapat sahabat, tabiin, para mufassir atau bahkan dengan kitab-kitab samawi (Taurat dan Injil), kemudian membandingkan dan menyeleksinya dengan menggunakan dalil-dalil yang lain. ${ }^{14}$

4. Tafsir al-Maudu'i adalah tafsir yang membahas tentang masalah-masalah alQur'an al-Karim yang (memiliki) kesamaaan makna atau tujuan dengan cara

\footnotetext{
${ }^{9}$ Muhammad Husain al-Dhahabi, 'Ilm al-Tafsir, (Kairo: Dar al-Ma'arif, t.th. ), 39

10 'Abd al-Hayy al-Farmawi, al-Bidayah fi al-Tafsir al-Maudui, (Kairo: al-Hadarah al-'Arabiyah, 1977), 23.

11 Fahd Ibn 'Ad al-Rumi, Buhuth fi Usul al-Tafsir wa Manahijuh, (t.tp. Maktabah al-Taubah, t.th.), 57.

12Abd al-Hayy al-Farmawi, al-Bidayah fi al-Tafsir al-Maudu'i, (Kairo: al-Hadarah al-'Arabiyyah, 1997), 24. bandingkan Ahmad Izzan, Metodologi Ilmu Tafsir, (Bandung: Tafakkur, 2009), 103.

${ }^{13}$ Fahd Ibn 'Ad al-Rumi, Buhuth fi Usul al-Tafsir , 59. Lihat Abd al-Hayy al-Farmawi, alBidayah fi al-Tafsir, 43. bandingkan Ahmad Izzan, Metodologi Ilmu Tafsir, 105.

${ }^{14}$ Fahd Ibn 'Ad al-Rumi, Buhuth fi Usul al-Tafsir wa Manahijuh, 55.
} 
menghimpun ayat-ayatnya untuk kemudian melakukan penalaran (analisis) terhadap isi kandungannya menurut cara-cara tertentu, dan berdasarkan syarat-syarat tertentu untuk menjelaskan makna-maknanya dan mengeluarkan unsur-unsurnya, serta menghubung-menghubungkan antara yang satu dan lainnya dengan korelasi yang yang bersifat komprehensif. ${ }^{15}$

Dari beberapa pemetaan para ulama terhadap metode penafsiran tersebut, menurut hemat penulis pemetaan al-Farmawi agaknya cukup relevan untuk dijadikan pedoman dalam memetakan metode tafsir. Sedangkan pemetaan al-Dhahabi nampaknya masih bersifat general antara sumber, metode, dan kecenderungan penafsiran.

Meskipun demikian, pemetaan metode al-Farmawi sebagaimana telah didefinisikan di atas, dalam implementasinya masih terdapat kerancuan antara metode satu dengan lainnya. Contohnya, metode tahlili yang poin utamanya menitikberatkan pada uraian-uraian penafsiran yang detail, mendalam, dan komprehensif itu terkadang ditempuh juga oleh metode muqarin dimana metode ini poin utamaya adalah mengumpulkan berbagai keterangan-keterangan tentang penafsiran sebuah ayat yang masih dalam satu pembahasan (baik berupa ayat alQuran, dengan hadis, pendapat sahabat, tabiin, para mufassir. Demikian juga metode Maudu'i yang titik poin utamanya adalah mengambil suatu tema, namun dalam implementasinya metode ini juga menggunakan metode tahlili bahkan juga menggunakan metode Muqarin. Hal-hal semacam ini tentunya akan menimbulkan tumpang tindih dan kerancuan dalam menganalisis sebuah tafsir dari sisi metode tafsirnya.

Oleh karena itu, menurut hemat penulis perlu pemetaan yang detail terhadap hal-hal yang berkaitan dengan penafsiran, baik dari sumber penafsiran, cara penjelasan/sistematika penyajian, keluasan penjelasan, sasaran dan tertib ayat yang ditafsirkan sebagaimana yang ditawarkan oleh M. Ridlwan Nasir dalam bukunya “Memahami Al-Qur'an, Perspektif Baru Metodologi Tafsir Muqarin .

\footnotetext{
${ }^{15}$ Ahmad Izzan, Metodologi, 114.
} 
Berdasarkan tawaran M. Ridlwan Nasir, maka menurut hasil pengamatan penulis terhadap tafsir al-Tibyan fi Aqsam al-Qur'an, metode yang di gunakan adalah sebagai berikut:

a. Apabila ditinjau dari sumber penafsirannya menggunakan metode bi aliqtirani (perpaduan antara bi al-manqul dan bi al-ma'thur) yaitu cara menafsirkan ayat-ayat al-Qur'an yang didasarkan atas perpaduan antara sumber riwayat yang kuat dan shahih dengan sumber ijtihad pikiran yang sehat. $^{16}$

Hal tersebut di atas dapat dilihat ketika Ibn Qayyim menafsirkan surat al-'Adiyat sebagai berikut:

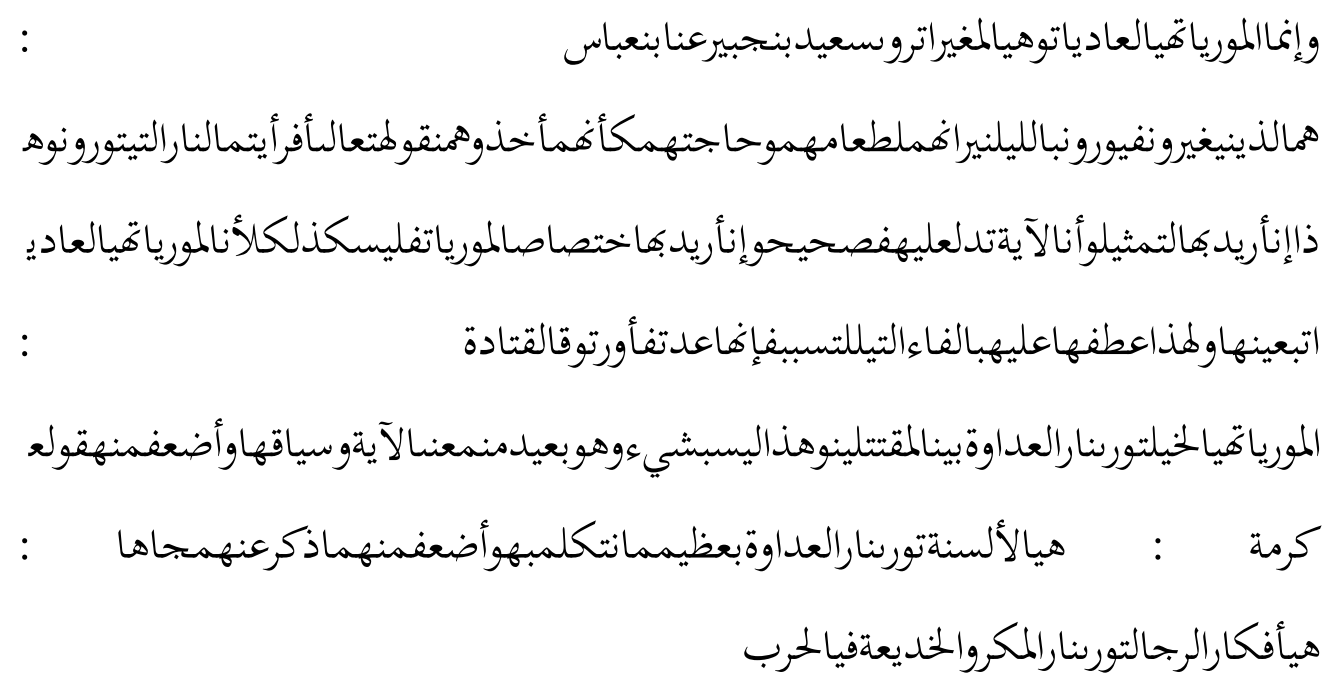

Ketika menafsirkan kata الموريات Ibn Qayyim memadukan antara beberapaa riwayat yaitu menukil riwayat Ibn Abbas yang dianggapnya sebagai riwayat yang sahih. Kemudian Ibn Qayyim juga menukil pendapat Qatadah dan Ikrimah yang dianggapnya sebagai pendapat yang lemah.

Penafsiran berikutnya Ibn Qayyim menyatakan;

$$
\begin{aligned}
& \text { وهذهالأقوالإنأريدأناللفظدلعليهاوأهاهيالمرادفغلطو إنأريدأهاأخذتمنطريقالإشارةوالقياس } \\
& \text { فأمرها قريب }
\end{aligned}
$$

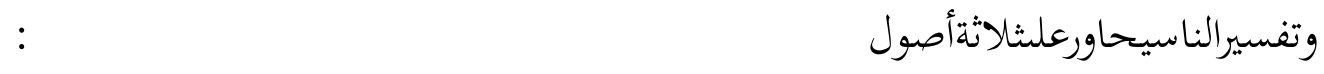

$$
\begin{aligned}
& \text { تفسيرعلاللفظوهوالذيينجو إليهالمتأخرونوتفسيرهعلالمعنوهوالذييذكرهالسلفوتفسيرعلالإشارة }
\end{aligned}
$$

${ }^{16}$ Ridwan Nasir, Memahami Al-Qur'an: Perspektif Baru Metodologi Tafsir Muqarin, (Surabaya: Indra Media, 2003), 15. 


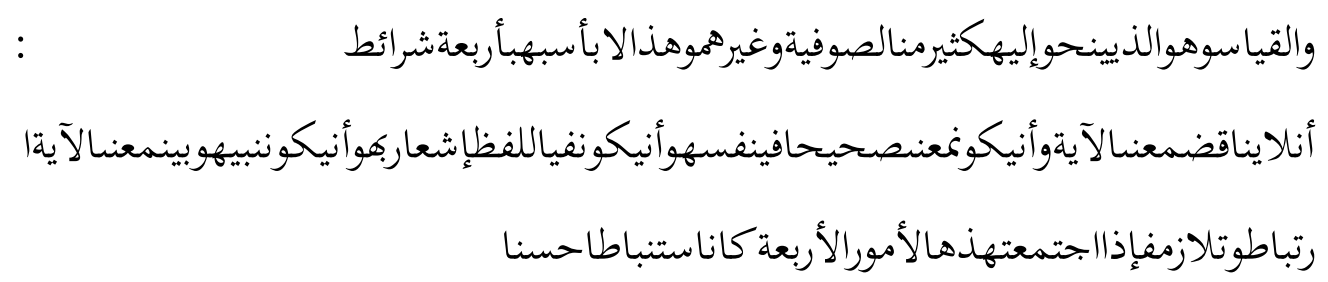

Penafsiran tersebut di atas merupakan hasil ijtihad Ibn Qayyim dalam menyimpulkan pendapat-pendapat yang sebelumnya telah dinukil. Langkah ini menunjukkan bahwa tafsir Ibn Qayyim ini sumber penafsirannya menggunakan perpaduan antara bi al-manqul dan bi al-ma'thur yang selanjutnya metode ini dinamakan dengan metode bi al-iqtirani.

b. Apabila ditinjau dari cara penjelasannya menggunakan metode muqarin atau komparasi yaitu membandingkan ayat dengan ayat yang lain dalam masalah yang sama, ayat dengan hadis (isi dan matan), antara pendapat mufassir dengan mufassir lain dengan menonjolkan segi-segi perbedaan. ${ }^{17}$

Kesimpulan di atas dapat dilihat dalam penafsiran Ibn Qayyim sebagai berikut:

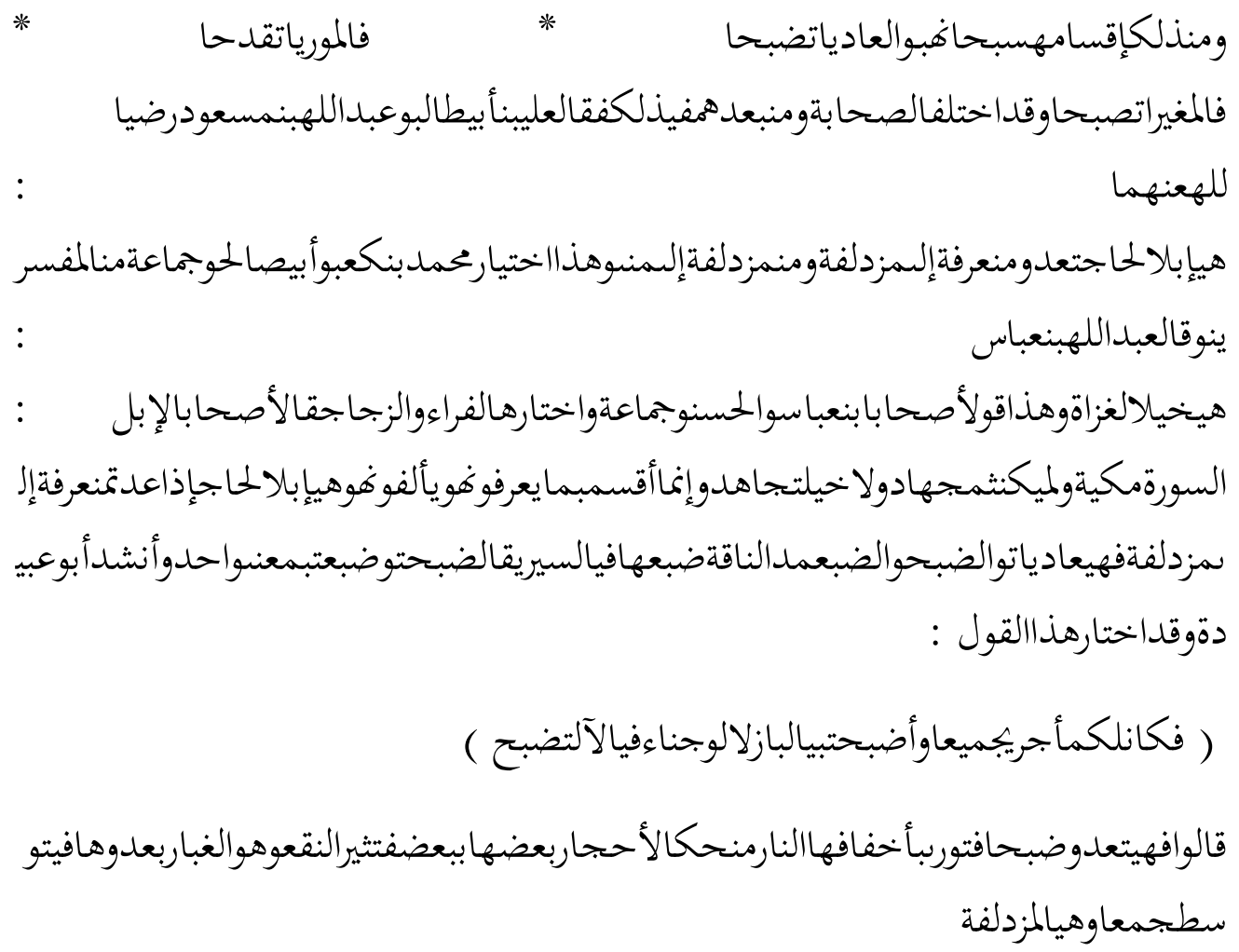

\footnotetext{
${ }^{17}$ Ridwan Nasir, Memahami Al-Qur'an: Perspektif Baru Metodologi, 16.
} 


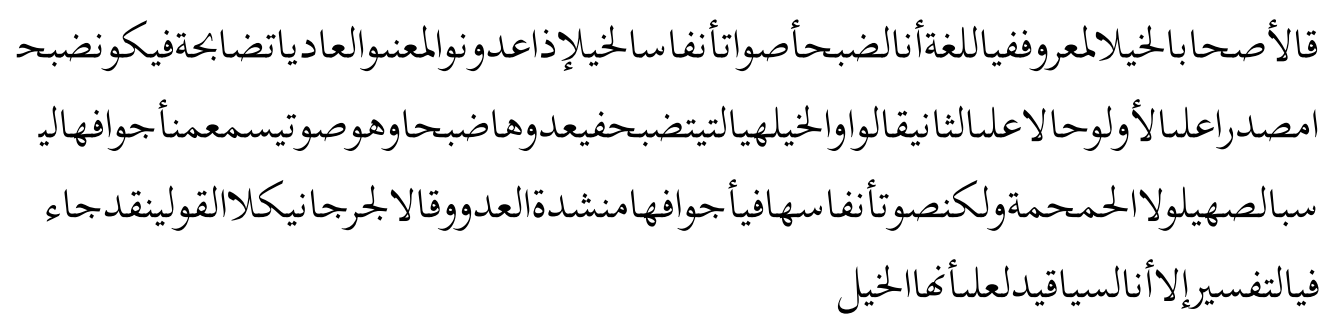

Dari penafsiran di atas, penulis melihat Ibn Qayyim mengutip beberapa pendapat dari kalangan sahabat, tabi'in atau ulama dan juga menonjolkan segi-segi perbedaan dari pendapat-pendapat. Penafsiran semacam ini seringkali juga dilakukan Ibn Qayyim dalam ayat-ayat yang lain. Oleh karena itu penulis berkesimpulan bahwa tafsir al-Tibyan ini jika dilihat dari sisi cara penjelasannya menggunakan metode muqarin.

c. Apabila ditinjau dari keluasan penjelasannya menggunakan Metode Ithnabi yaitu penafsiran dengan cara menafsirkan ayat-ayat al-Qur'an secara mendetail atau rinci, dengan uraian-uraian yang panjang lebar, sehingga cukup jelas dan terang yang banyak disenangi oleh para cerdik pandai. ${ }^{18}$

Hal ini dapat dilihat dari beberapa contoh penafsiran di atas dimana Ibn Qayyim sangat detail dalam menafsirkan ayat. Disamping itu, secara umum dapat dikatakan bahwa tafsir yang cara penjelasannya menggunakan metode muqarin hampir dapat dipastikan bahwa keluasan penjelasannya akan menggunakan metode Ithnabi.

d. Apabila ditinjau dari sasaran dan tartib ayat yang ditafsirkan (sistematika penyajian runtut) menggunakan metode Maudu'i yaitu suatu penafsiran dengan cara mengumpulkan ayat mengenai satu judul/topik tertentu, dengan memperhatikan masa turunnya dan asbab nuzul-nya ayat, serta dengan mempelajari ayat-ayat tersebut secara cermat dan mendalam dengan memperhatikan hubungan ayat yang satu dengan ayat yang lain di dalam menunjuk suatu permasalahan, kemudian menyimpulkan masalah yang dibahas dari dilalah ayat-ayat yang ditafsirkan secara terpadu. ${ }^{19}$

Dalam tafsir al-Tibyan fi Aqsam Al-Qur'an ini, Ibn Qayyim nampaknya ingin menjelaskan masalah sumpah secara detail dan mendalam.

${ }^{18}$ Ridlwan Nasir, Memahami Al-Qur'an ..., 16

${ }^{19}$ Ridlwan Nasir, Memahami Al-Qur'an ...,, 17 
Agar tujuan tersebut tercapai, maka Ibn Qayyim mengambil satu tema tentang sumpah yang ditafsirkan secara detail dengan memperhatikan masa turunnya dan $a s b a\} b$ nuzul-nya ayat, serta dengan mempelajari ayat-ayat tersebut secara cermat dan mendalam dengan memperhatikan hubungan ayat yang satu dengan ayat yang lain. Oleh karena itu penulis menyimpulkan bahwa metode yang digunakan dalam tafsir ini adalah metode Maudu'i dengan definisi sebagaimana dijelaskan sebelumnya.

Selain argumentasi di atas, dengan membaca nama yang diberikan kepada kitab tafsir ini, yaitu "al-Tibyan fi Aqsam Al-Qur'an" (penjelasan terhadap sumpah yang ada dalam al-Qur'an), sepintas sudah dapat disimpulkan bahwa yang dibahas dalam tafsir ini adalah seputar masalahmasalah yang berkaitan dengan sumpah yang tentunya ini merupakan ciri-ciri dari tafsir yang menggunakan metode Maudu'i.

\section{Kecenderungan Tafsir Al-Tibyan Fi Aqsam Al-Qur'an}

Dalam 'Ulum al-Qur'an terdapat istilah al-Ittijah atau al-Naz'ah. Menurut M. Ibrahim Syarif sebagaimana dikutib M. Ridlwan Nasir, al-Ittijah atau al-Naz'ah adalah sekumpulan dari mabadi' (dasar pijakan) pemikiran yang jelas yang tercakup dalam satu teori dan mengarah pada satu tujuan. ${ }^{20} a l$-Ittijah atau al-Naz'ah inilah yang oleh M. Ridlwan Nasir diartikan sebagai aliran atau kecenderungan (aliran) sebagaimana yang dimaksudkan dalam tulisan ini, meskipun Amad Izzan membedakan antara aliran dan aliran. Kecenderungan yang dimaksud disini adalah arah penafsiran yang menjadi kecenderungan para mufassir dalam menafsirkan ayatayat al-Qur'an yang oleh Ahmad Izzan disebut dengan aliran atau al-Laun. ${ }^{21}$

Berkaitan dengan kecenderungan (aliran) atau aliran tafsir al-Tibyan fi Aqsam al-Qur'an ini, ada beberapa hal yang perlu dicermati dengan seksama. Hal ini perlu dilakukan dikarenakan tafsir al-Tibyan fi Aqsam al-Qur'an ini merupakan tafsir Maudu'i,. dimana tafsir yang menggunakan metode ini sistematika penyajian dan penjelasannya tentunya sangat kompleks dan komprehensif. Sangat memungkinkan dalam tafsir yang menggunakan metode Maudu'i ini mempunyai

${ }^{20}$ Ridlwan Nasir, Memahami Al-Qur'an..., 18

${ }^{21}$ Ahmad Izzan, Metodologi, 199. Lihat Forum Karya Ilmiyah RADEN, Al-Qur'an Kita: Studi, Sejarah dan Tafsir Kalmullah, ed. Abu Hafsin (Kediri: Lirboyo Press, 2011), 241. 
beberapa kecenderungan atau aliran untuk menyajikan penafsiran secara detail dan komprehensif.

Sebagai bagian dari tafsir yang menggunakan metode Maudu'i, tidak menutup kemungkinan tafsir al-Tibyan fi Aqsam al-Qur'an juga mempunyai beberapa kecenderungan atau aliran. Untuk sampai pada sebuah kesimpulan tentang kecendurangan atau aliran tafsir al-Tibyan fi Aqsam al-Qur'an ini, penulis menyajikan sedikit gambaran tentang pembahasan yang terdapat dalam tafsir ini alTibyan fi Aqsam al-Qur'an.

Sesuai dengan namanya tafsir ini membahas tentang hal-hal yang berkaitan dengan sumpah. Lazimnya sumpah bertujuan untuk memperkuat informasi yang disampaikan oleh pembawa informasi. Allah swt. sebagai pembawa informasi memperkuat informasi-Nya (muqsam 'alaih) dengan berbagai macam hal (muqsam bih) yang semuanya menunjukkan atas tanda kebesaran kekuasaan-Nya. Untuk menjelaskan tentang muqsam 'alaih dan muqsam bih inilah penafsir nampaknya menggunakan pendekatan kajian yang menitik beratkan pada unsur-unsur kejiwaan. Hal ini dapat dilihat dalam pasal 10 yang terjemahnnya kurang lebih sebagai berikut;

Diantaranya sumpah Allah Swt. adalah:

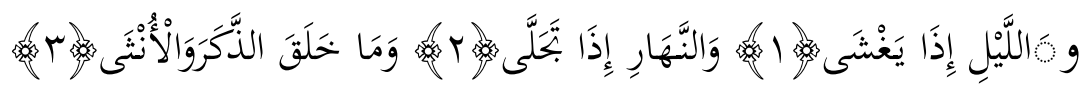

Demi malam apabila menutupi (cahaya siang).

Dan siang apabila terang benderang,

Dan penciptaan laki-laki dan perempuan ${ }^{22}$,

Dalam ayat ini Allah Swt bersumpah dengan malam dengan seluruh keadaannya, karena malam merupakan tanda-tanda yang menunjukkan kekuasaanNya. Allah bersumpah dengan malam pada waktu gelap gulita dan sumpah ini didatangkan dengan bentuk fi'il Mudlari' karena gelapnya malam berjalan sedikit demi sedikit. Adapun siang apabila matahari terbit maka sekaligus akan tampak dan jelas.

Dalam ayat ini Allah Swt juga menuturkan tiga penyebab yang bisa memudahkan suatu kemudahan (surga). Pertama, memberi sesuatu yang

\footnotetext{
${ }^{22}$ Wizarah al-Suun al-Islamiyah, Al-Qur'an dan terjemahnya, (Madinah: Mujamma' al-Malik Fahd li Tiba'at al Mushaf, 1418), 1067.
} 
diperintahkan dengan diikuti oleh jiwa ihlas. Kedua, taqwa yaitu menjauhi segala hal yang dilarangnya. Inilah penyebab kemudahan yang paling besar. Ketiga, membenarkan pahala yang terbaik (al-Husna).

Apabila kita mau merenungkan apa yang terkandung dalam tiga kalimat ini (memberikan sesuatu, taqwa dan membenarkan pahala yang terbaik) maka sesungguhnya nafsu itu mempunyai tiga kekuatan; kekuatan menyerahkan dan memberi, kekuatan mencegah dan menolak dan kekuatan menemukan dan memahami. Didalamnya terdapat kekuatan pengetahuan dan perasaan yang diikuti dengan kekuatan cinta dan kemauan dan kekuatan kebencian dan pelarian. Ketiga kekuatan inilah yang menjadi poros kebaikan dan keberentungan jiwa. Apabila rusak tiga kekuatan ini maka rusaklah jiwa. Rusaknya kekuatan ilmu dan perasaan menyebabkan terhadap pendustaan terhadap pembalasan yang baik. Rusaknya kekuatan cinta dan kehendak akan menyebabkan tidak mau memberi. Rusaknya kekuatan benci dan lari menyebabkan meninggalkan ketaqwaan. Apabila kekuatan cinta dan kehendak sempurna dengan memberikan apa yang diperintahkan, dan kekuatan kekuatan benci dan lari sempurna dengan meninggalkan apa yang dilarang, dan kekuatan ilmu dan perasaan sempurna dengan membenarkan kalimat Islam serta hak-hak dan pembalasannya, maka jiwa akan bersih dan jadilah nafsu memudahkan kepada kemudahan (surga).

Adapun orang yang pelit maka kosong kekuatan kehendak dan kekuatan untuk memberikan apa yang diperintahkan. Demikian juga orang yang merasa tidak butuh (istaghna) dengan cara meninggalkan taqwa kepada Allah Swt, maka kosonglah kekuatan mencegah dan meninggalkan dari apa yang dilarangnya. Orang yang mendustakan pahala yang terbaik (wa kazhzhaba bi al-Husna), maka kosonglah kekuatan ilmu dan perasaannya sehingga tidak mau membenarkan tentang keimanan dan balasannya. Orang-orang itulah yang akan dimudahkan kepada kesulitan (neraka). ${ }^{23}$

Selain itu, sebagai pendukung penafsirannya, sering kali penafsir menggunakan pendekatan bahasa dengan cara menguraikan maksud dari kalimat secara detail dengan berbagai sumber. Hal ini dapat dilihat pada pasal 5 yang terjemahannya kurang lebih sebagai berikut;

${ }^{23}$ Ibn Qayyim al-Jauziyah, al-Tibyan fi Aqsam al-Qur'an (Beirut: Dar al-Fikr, t.th.), 35. 
Diantara sumpah atas sifat manusia adalah firman Allah Swt.:

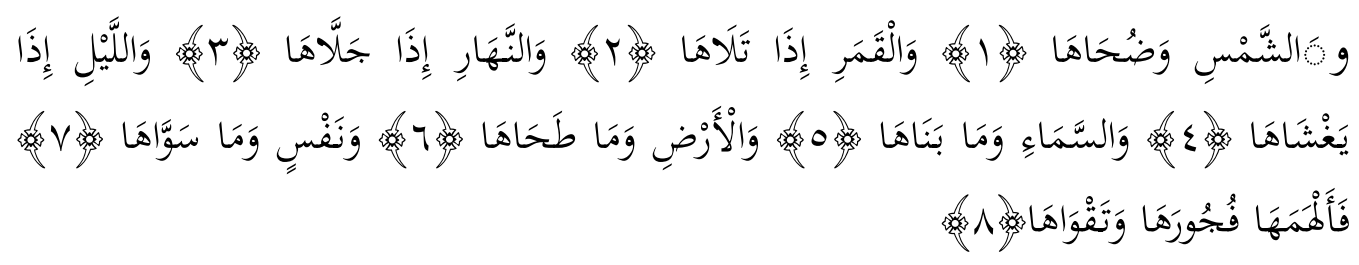

1. demi matahari dan cahayanya di pagi hari,

2. dan bulan apabila mengiringinya,

3. dan siang apabila menampakkannya,

4. dan malam apabila menutupinya

5. dan langit serta pembinaannya,

6. dan bumi serta penghamparannya,

7. dan jiwa serta penyempurnaannya (ciptaannya),

8. Maka Allah mengilhamkan kepada jiwa itu (jalan) kefasikan dan ketakwaannya. $^{24}$

al-Zujaj dan yang lainnya mengatakan bahwa jawab sumpah ini adalah:

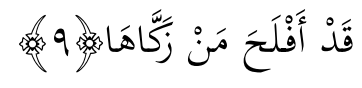

Sesungguhnya beruntunglah orang yang mensucikan jiwa itu. ${ }^{25}$

Ketika kalimat sangat panjang maka sangat baik kalau huruf Lam dibuang dari jawab. Sumpah ini mengandung sumpah dengan Khaliq dan Makhluq.Allah Swt. bersumpah dengan langit dan pembinaannya, dan bumi serta penghamparannya dan jiwa serta penyempurnaan (ciptaannya).

Dalam ayat ini Allah Swt bersumpah dengan ciptaan-Nya yang secara otomatis menunjukkan keberadaan-Nya, dan juga bersumpah dengan penciptaan yang menunjukkan atas kesempurnaan pengetahuan, kekuasaan, kebijaksanaan dan keesaan-Nya. Ketika pergerakan matahari dan bulan, malam dan siang merupakan sesuatu yang telah disaksikan kebaharuannya oleh manusia sedikit demi sedikit, dan manusiapun tahu bahwa sesuatu yang baru pasti membutuhkan pembaharu, maka pengetahuan itu menempati posisi mengingat terhadap pembaharu secara lafad, maka $f a>$ 'il (pembuat) tidak perlu disebutkan dalam keempat sumpah tersebut.

\footnotetext{
${ }^{24}$ Wizarah al-Suun al-Islamiyah, Al-Qur'an dan terjemahnya, 1064.

${ }^{25}$ Wizarah al-Suun al-Islamiyah, Al-Qur'an ..., 1064.
} 
Di dalam sumpah ini terdapat perselisihan tentang nafsu yang dijadikan sumpah. Apakah nafsu yang dimaksud itu nafsu khusus atau nafsu secara umum. Ada dua pendapat berdasarkan atas tiga pendapat tentang al-Lawwamah. Ibn Abbas berkata "Setiap jiwa akan mencela dirinya nanti pada hari kiamat, orang yang berbuat baik akan mencela dirinya untuk tidak menambah kebaikannya, dan orang yang berbuat jelek akan mencela untuk tidak mengulangi kesalahannya. Pendapat inilah yang dipilih oleh al-Farra', dan ia berkata bahwa tidak adapun jiwa baik yang baik ataupun yang jelek yang tidak mencela dirinya, apabila jiwa berbuat baik maka ia akan berkata "mengapa tidak menambah kebaikannya?" dan apabila berbuat kejelekan maka ia akan berkata" Sekiranya aku tidak berbuat".

Pendapat kedua mengatakan bahwa yang dimaksud nafsu adalah nafsu yang khusus. Hasan mengatakan bahwa nafsu yang dimaksudkan adalah al-nafs almu'minah. Pendapat ketiga mengatakan bahwa yang dimaksudkan nafsu adalah alnafs al-kafirah. Pendapat ini adalah pendapat Muqatil dan Qatadah. Nafsu yang dimaksudkan adalah al-nafs al-Kafirah. Nafsu ini akan mencela dirinya pada hari kiamat atas kelengahan terhadap perintah Allah. ${ }^{26}$

Selain tersebut di atas, menurut pengamatan penulis tafsir ini nampak juga beraliran ilmiyah. Kesimpulan ini didasarkan atas sering kalinya penafsir membahas hal-hal yang berkenaan dengan ilmu pengetahuan umum. Sebagai contoh dapat dilihat dalam pasal 107 sebagai berikut;

Apabila dipertanyakan" apakah mungkin janin itu terjadi dari dua air dan dua orang yang menyetubuhi. Dikatakan bahwa ini adalah masalah syari'at yang berbentuk hukum alam. Sedangkan syari'at itu selalu ikut hukum alam. Masalah ini sungguh telah diperselisihkan baik secara syar'i maupun perkiraan. Sebagian ulama menolak masalah ini dan mereka berkata bahwa apabila air mani telah menetap pada rahim maka sudah termuat dan terkumpul semua dengan kata lain tidak ada sekadar pucuk jarumpun yang terbuka, semuanya sudah tertutup. Untuk itu tidak mungkin rahim itu terbuka lagi untuk menerima air mani yang kedua baik dari orang yang menyetubuhi itu sendiri atau dari orang lain. Mereka berkata " untuk itu Allah memberlakukan kebiasaan bahwa anak tidak mempunyai bapak 
kecuali satu seperti halnya tidak mempunyai ibu kecuali satu. Pendapat ini adalah pendapatnya madhab Imam syafi'i.

Sebagian ulama lagi mengatakan bahwa janin bisa terjadi dari dua air mani atau bahkan lebih. Terkumpul dan termuatnya air mani dalam rahim tidak bisa menghalangi masuknya air mani yang kedua karena rahim adalah sesuatu yang sangat penasaran dan sangat menerima terhadap mani. Mereka berkata bahwa hal itu tidak berbeda dengan saluran makanan. Makanan yang sudah berada dan terkumpul di dalamnya apabila datang makanan di atasnya maka saluran itu akan terbuka karena ia sangat penasaran terhadap makanan.

Mereka berkata bahwa masalah ini telah dipersaksikan oleh seorang yang ahli jejak nasab (Qaif) kehadapan Umar bin Khatt ab pada masalah seorang anak yang diakui oleh dua orang. Setelah qaif itu melihat kedua orang tersuat dan anak, maka ia berkata bahwa ia tidak melihat kedua orang itu kecuali kedua ikut memiliki anak tersebut. Hal ini disepakati oleh Umar dan nasab anak itu diikutkan kepada keduanya. Hal inilah yang juga disepakati Imam Ahmad dan Imam Malik.

Mereka berkata bahwa hal itu bisa disaksikan secara empiris seperti yang bisa dilihat pada anjing dan kucing yang anak-anaknya lahir dengan macammacam warna karena banyak bapaknya. Rasulullah telah bersabda" barang siapa beriman kepada Allah dan hari akhir maka janganlah menyiramkan airnya pada tanaman orang lain" yang maksudnya adalah tidak boleh menyetubuhi orang hamil kecuali orang yang telah menghamilinya. Imam Ahmad berkata" Setubuh itu bisa menambah pendengaran dan penglihatan anak.

Dalam hal ini adalah terdapat masalah fikih, yaitu:

Apabila ada seseorang menghamili hamba sahaya perempuan (jariyah) orang lain baik dengan nikah ataupun zina lalu dimiliki, apakah jariyah tersebut menjadi Uтmи Walad? Ada empat pendapat menurut riwayat dari Imam Ahmad.

Pertama: jariyah tersebut tidak bisa menjadi Ummu Walad karena jariyah tersebut tidak bisa berkaitan dengan anak dalam kepemilikannya. 
Kedua: jariyah tersebut menjadi ummu walad karena bayi itu lahir dalam kepemilikannya.

Ketiga: apabila jariyah melahirkan dalam kepemilikannya maka menjadi Uтти Walad dan apabila melahirkan sebelum dalam kepemilikannya maka tidak bisa menjadi Ummu Walad karena lahir dan mengandungnya tidak dalam kepemilikannya.

Keempat: apabila jariyah itu disetubuhi setelah dimiliki maka menjadi Uтmи Walad, apabila tidak maka tidak menjadi Ummu Walad, karena setubuh bisa menambah kejadian anak seperti yang dikatakan Imam Ahmad bahwa setubuh bisa menambah pendengaran dan penglihatan anak. Inilah pendapat yang paling unggul. ${ }^{27}$

Berdasarkan dari gambaran penafsiran tersebut di atas, dapat disimpulkan bahwa dalam tafsiral-Tibyan fi Aqsam al-Qur'an terdapat beberapa kecenderungan/aliran yang digunakan, yaitu:

1. Aliran al-Sufi yaitu tafsir yang beraliran tasawwuf, kajiannya menitik beratkan pada unsur-unsur kejiwaan. ${ }^{28}$

2. Aliran Lughawi, yaitu tafsir yang menitik beratkan beratkan pada unsur bahasa. $^{29}$

3. Aliran 'Ilmi, yaitu tafsir yang beraliran ilmiyah, yang titik sentral kajiannya bidang ilmu pengetahuan umum, untuk menjelaskan ayat-ayat al-Qur'an, terutama berkisar pada soal-soal alam (fisika) atau ayat-ayat kauniyah. ${ }^{30}$

4. Aliran al-Fiqhi, yaitu tafsir al-Qur'an yang beraliran fiqh yang titik sentralnya pada bidang hukum. ${ }^{31}$

Keempat aliran tersebut memang mewarnai dalam tafsir at-Tibyan dikarenakan tafsir ini merupakan bagian dari tafsir Maudlui yang dalam penjelasannya dituntut untuk detail dan mendalam sehingga segala aliran dan metode tentu akan digunakan demi untuk menyampaikan penjelasan yang detail dan mendalam. Namun demikian menurut penulis bukan berarti tafsir at-Tibyan ini

\footnotetext{
${ }^{27}$ Ibn Qayyim al-Jauziyah, al-Tibyan..,, 222.

${ }^{28}$ Ridlwan Nasir, Memahami al-Qur'an ..., 19.

${ }^{29}$ Ridlwan Nasir, Memahami al-Qur'an..., 18.

${ }^{30}$ Ridlwan Nasir, Memahami al-Qur'an ..., 19

${ }^{31}$ Ridlwan Nasir, Memahami al-Qur'an..., 18.
} 
mempunyai empat aliran berdasarkan aliran yang mewarnai di dalamnya, akan tetap aliran atau kecenderungan yang dominan yaitu aliran shufi itulah yang menjadi ciri-ciri aliran atau kecenderungan sebuah tafsir.

\section{KESIMPULAN}

Berdasarkan dari pemaparan tulisan tersebut di atas dapat disimpulkan bahwa;

1. Sumber penelitian yang digunakan dalam tafsir Tafsir Al-Tibyan fi Aqsam al-Qur'an adalah bil Iqtiran (perpaduan antara bil Ma'tsur dan bil Ra'y)

2. Metode yang dipakai Tafsir Al-Tibyan fi Aqsam al-Qur'an adalah sebagai berikut:

a. Apabila dilihat dari cara penjelasannya menggunakan metode Bayani.

b. Apabila dilihat dari keluasan penjelasannya menggunakan metode Itnabi.

c. Apabila dilihat dari sasaran \& dan sasaran ayat yang ditafsirkan menggunakan metode Maudu'i.

1. Tafsir Al-Tibyan fi Aqsam al-Qur'an memiliki beberapa aliran/kecenderungan, yaitu: aliran Sufi, Lughawi, 'Ilmi, dan al-Fiqhi, namun aliran yang paling dominan adalah aliran shufi.

\section{REFERENSI}

Dhahabi (al), Muhammad Husain, 'Ilm al-Tafsir, Kairo: Dar al-Ma'arif, t.th..

Farmawi (al), Abd al-Hayy, al-Bidayah fi al-Tafsir al-Maudu'i, Kairo: al-Hadarah al'Arabiyyah, 1997.

Izzan, Ahmad, Metodologi Ilmu Tafsir, Bandung: Tafakkur, 2009.

Jauziyah (al), Ibn Qayyim, al-Fawaid, Beirut, Dar al-Kutub al-'Ilmiyah, 1973. , al-Tibyan fi Aqsam al-Qur'an, Beirut: Dar al-Fikr, t.th.

Kathir, Ibn, al-Bidayah wa al-Nihayah, t.tp. Dar Ihya' al-Turath al-“arabi, 1988.

Nasir, Ridwan, Memahami Al-Qur'an: Perspektif Baru Metodologi Tafsir Muqarin, Surabaya: Indra Media, 2003.

'Uwaydah, Kamil Muhammad Muhammad, al-Imam al-Hafiz Syams al-Din, Beirut: Dar al-Kutub al-Ilmiyyah, t.th.

Raden, Forum Karya Ilmiyah, Al-Qur'an Kita: Studi, Sejarah dan Tafsir Kalmullah, ed. Abu Hafsin, Kediri: Lirboyo Press, 2011.

Rumi (al), Fahd Ibn 'Ad, Buhuth fi Usul al-Tafsir wa Manahijuh, t.tp. Maktabah alTaubah, t.th..

Sabuni (al), 'Ali, al-Tibyan fi 'Ulum al-Qur'an, Beirut: Dar al-'Ilm al-Kutub, t.th.. 
Salih, Subhi, Mabahith fi 'Ulum al-Qur'an, Beirut: Dar al-'Ilm al-Malyin, 1988.

Zarqani, Abd al-'Azim, Manahil al-'Irfan fi 'Ulum al-Qur'an, vol. II, Kairo: Dar alHadith, 2001. 